Journal of Marine Systems

January 2017, Volume 165, Pages 115-123

http://dx.doi.org/10.1016/i.jmarsys.2016.10.005

http://archimer.ifremer.fr/doc/00354/46507/

(c) 2016 Elsevier B.V. All rights reserved.

\title{
Habitat use and diving behaviour of gravid olive ridley sea turtles under riverine conditions in French Guiana
}

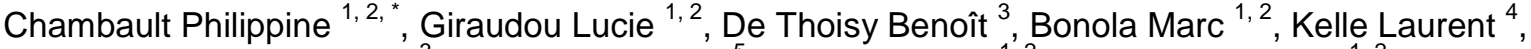 \\ Dos Reis Virginie ${ }^{3}$, Blanchard Fabian ${ }^{5}$, Le Maho Yvan ${ }^{1,2}$, Chevallier Damien ${ }^{1,2}$
}

${ }^{1}$ Université de Strasbourg, Institut Pluridisciplinaire Hubert Curien, 23 rue Becquerel, F-67087 8

Strasbourg Cedex 2, France

${ }_{2}^{2}$ CNRS, UMR 7178, 23 rue Becquerel, F-67087 Strasbourg Cedex 2, France

${ }^{3}$ Association Kwata, 16 avenue Pasteur, BP 672, F-97335 Cayenne Cedex, France

${ }^{4}$ WWF Guyane, N 5 Lotissement Katoury, F-97300 Cayenne, France

${ }^{5}$ UMSR LEEISA, Université de Guyane, CNRS, IFREMER, Délégation Ifremer de Guyane, Domaine de

Suzini, BP 477, F-97331 Cayenne, France

* Corresponding author : Philippine Chambault

\begin{abstract}
:
The identification of the inter-nesting habitat used by gravid sea turtles has become a crucial factor in their protection. Their aggregation in large groups of individuals during the inter-nesting period exposes them to increased threats to their survival - particularly along the French Guiana shield, where intense legal and illegal fisheries occur. Among the three sea turtle species nesting in French Guiana, the olive ridley appears to have the most generalist diet, showing strong behavioural plasticity according to the environment encountered. The large amounts of sediments that are continuously discharged by the Amazon River create a very unusual habitat for olive ridleys, i.e. turbid waters with low salinity. This study assesses the behavioural adjustments of 20 adult female olive ridleys under such riverine conditions. Individuals were tracked by satellite from Remire-Montjoly rookery in French Guiana using tags that recorded the location and diving parameters of individuals, as well as the immediate environment of the turtles including the in situ temperature and salinity. Data concerning potential preys was provided via collection of epifauna by a trawler. Multiple behavioural shifts were observed in both horizontal and vertical dimensions. During the first half of the inter-nesting season, the turtles moved away from the nesting beach $(27.6 \pm 26.4 \mathrm{~km})$, performing deeper $(14.2 \pm 8.7 \mathrm{~m})$ and longer $(33.2 \pm$ $22.2 \mathrm{~min})$ dives than during the second half of the period $(8.6 \pm 10.3 \mathrm{~km}, 10.6 \pm 5.1 \mathrm{~m}$ and $26.4 \pm 19.4$ $\mathrm{min}$ ). Olive ridleys remained in waters that were warm (range: $26-33^{\circ} \mathrm{C}$ ) and which fluctuated in terms of salinity (range: 19.5-36.4 psu), in a relatively small estuarine habitat covering $409 \mathrm{~km} 2$. If olive ridleys were foraging during this period, the potential preys that might be available include were mostly crustaceans (47\%) and fish (26\%), as expected for the diet of this generalist species during this period. This study highlights the numerous behavioural adaptations of this species in response to the unusual riverine conditions of the French Guiana continental shelf.
\end{abstract}




\section{Highlights}

- 20 gravid olive ridley sea turtles were tracked by satellite from French Guiana $>$ Data for turtle location, diving behaviour and the estuarine environment - The habitat used covered $423 \mathrm{~km}^{2}$ and the waters were variable in terms of salinity - The epifauna sampled was mostly crustaceans (43\%) and fish (39\%) D Dives were deeper and longer during the first half of the inter-nesting season

Keywords : Lepidochelys olivacea, Equatorial Atlantic, Inter-nesting season, Behavioural synchrony, Amazon River 


\section{Introduction}

The tracking of highly mobile organisms through satellite telemetry helps to identify key breding and foraging areas that play a crucial role in species conservation (Stokes et al. 2015). Given the high inter-individual plasticity of these migrant organisms, long-term monitoring is usually required to delineate adequate protected areas based on species distribution (Schofield et al. 2010). A better understanding of how animals interact with their environment is therefore needed to implement efficient conservation measures, especially when dealing with threatened species such as sea turtles.

The use of satellite tracking to study sea turtles movements and their habitat use during the breeding-nesting season highlighted strong site fidelity for both males and females (Schofield et al. 2010, Hays et al. 2014, Chambault, De Thoisy, Kelle, et al. 2016). The identification of such habitat is of major importance due to the large aggregation of individuals close to the nesting beaches during this period. Additionally, such periods make sea turtles particularly vulnerable due to the high energy costs of the reproduction and the nesting activities. An evaluation of the home range is an essential tool to establish a picture of the core activity areas for the protection of such endangered species (Scott et al. 2012, Schofield et al. 2013, Pendoley et al. 2014). This tool has been widely used to support conservation initiatives for leatherback (Witt et al. 2008), kemp ridley (Seney \& Landry), loggerhead (Schofield et al. 2010, Hart et al. 2010), green (Richardson et al. 2013, Hart et al. 2013, Blanco et al. 2013), hawksbill turtles (Marcovaldi et al. 2012, Hart et al. 2012, Revuelta et al. 2015) and olive ridley (Maxwell et al. 2011).

During the inter-nesting season, olive ridley sea turtles show a strong behavioural plasticity in their dispersal and diving behaviour (Hamel et al. 2008, Maxwell et al. 2011, Pikesley et al. 2013). According to the geographic area and therefore the resources available, olive ridleys can adopt either a capital breeding strategy, in which they store fat reserves at their foraging grounds and then cease to feed during the breeding-nesting season (Drent \& Daan 1980), or use an income breeding strategy, whereby they continue to feed throughout the reproduction period (Miller 1997, Colman et al. 2014).

The olive ridley is distributed across all tropical and subtropical waters, and appears to be the most abundant sea turtle species (Godfrey \& Godley 2008). This species has been studied in the Pacific (Polovina et al. 2004, Swimmer et al. 2006, 2009, Plotkin 2010), the Arafura Sea off Northern Australia (Whiting et al. 2007, McMahon et al. 2007, Hamel et al. 2008, Pikesley et al. 2013), and in the Indian (Rees et al. 2012) and Atlantic Ocean (Reis et al. 
2010, Maxwell et al. 2011). In the western part of the Equatorial Atlantic, French Guiana hosts one of the largest population of olive ridleys (Kelle et al. 2009, "SWOT" 2016). The olive ridley population of French Guiana has already been tracked during post-nesting migration (Plot et al. 2015, Chambault, De Thoisy, Heerah, et al. 2016), but only one study to date has focused on the movements and diving behaviour of this species during the internesting season, highlighting the surprising reproductive synchrony of olive ridleys nesting in French Guiana (Plot et al. 2012).

The Guianese continental shelf is strongly enriched by the large amounts of sediments and suspended materials that are continuously discharged by the Amazon River (Milliman \& Meade 1983, DeMaster et al. 1996), creating turbid and warm waters that fluctuate drastically in terms of salinity between the dry and the rainy season. Given the active behaviour adopted by this population during the post-nesting migration (Chambault, De Thoisy, Heerah, et al. 2016) and the inter-nesting season (Plot et al. 2012), and in view of the abundance of potential prey for olive ridleys over the French Guiana shield (Guéguen 2000), we hypothesize that gravid females nesting in French Guiana will dive consistently, adjusting their behaviour to the fluctuating conditions encountered on the Guianese continental shelf.

To assess olive ridley behavioural shifts in response to estuarine conditions, twenty adult females were equipped with satellite tags on Remire-Montjoly beaches (French Guiana) in 2013 and 2014. The tags recorded the behaviour (location and diving parameters) of animals and sampled the in situ temperature and salinity of their immediate environment. Combined with the details of available prey collected in trawl nets, the information supplied by these tags will help to characterize (1) the displacements and (2) the diving behaviour of this vulnerable species in this unusual habitat during the energetically costly inter-nesting season.

\section{Methods}

\subsection{Ethics statements}

This study meets the legal requirements of the countries where this work was carried out, and follows all institutional guidelines. The protocol was approved by the "Conseil National de la Protection de la Nature" (CNPN, http://www.conservationnature.fr/acteurs2.php?id=11), the French Ministry for Ecology, Sustainable Development and Energy (permit Number: 09/618) acting as an ethics committee in French Guiana. After 
the evaluation of the project by the CNPN, fieldwork was carried out in strict accordance with the recommendations of the Police Prefecture of French Guiana, Cayenne, France, in order to minimize the disturbance of animals.

\subsection{Study site and animal tagging}

During the inter-nesting seasons in 2013 and 2014, 20 adult female olive ridleys were fitted with satellite tags on Remire-Montjoly beaches $\left(4.53^{\circ} \mathrm{N},-52.16^{\circ} \mathrm{W}\right.$, Cayenne, French Guiana). From 26/06/13 to 29/06/13, 8 Argos-linked Fastloc GPS tags (MK10, Wildlife Computers Redmond, WA, USA) and 2 Conductivity Temperature Depth FluorometerSatellite Relayed Data Loggers (CTD-SRDL, Sea Mammal Research Unit, University of St. Andrews, Scotland) were deployed. From 25/06/14 and 30/07/2014, 10 additional CTDSRDL tags were fitted on olive ridleys. The attachment procedure followed the standard methods described in Baudouin et al. (2015).

\subsection{Data collection}

\subsubsection{Nocturnal patrols}

Nesting events were identified using direct observation during nocturnal surveys rather than evidence of haul-outs from tracking data. This choice is explained by the lack of precise resolution from the Argos $(>1500 \mathrm{~m})$ and GPS locations $(<100 \mathrm{~m})$ and the potential inaccuracy of the GEBCO database in such coastal habitat, making the identification of nesting events unreliable if based on tracking data alone. Daily nocturnal patrols were therefore performed from April to September in 2013 and 2014 on Remire-Montjoly and Cayenne beaches to observe the entire nesting season of olive ridley turtles. Using the same procedure as that described in Chambault et al. (2016), each observed female was scanned with a TROVAN Reader to identify a Passive Integrated Transponder (PIT) and if the individual was not tagged, a PIT was inserted in the top right triceps muscle. To complete these nocturnal patrols, daily counts of female's traces on the beach were conducted each day to ensure that no nesting event was missed.

\subsubsection{Argos-linked Fastloc GPS tags}

The procedure to extract the inter-nesting route data was identical to that used in Baudouin et al. (2015). The Argos-linked Fastloc GPS tags recorded Argos locations and GPS positions at 4 -hour intervals ( $<1 \%$ of the locations transmitted). These tags also provided diving data, i.e. maximum dive depths, dive durations and in situ temperature data, binned as 
4-hour period histograms. Maximum depths were collected in different bins, every $10 \mathrm{~m}$ from 10 to $100 \mathrm{~m}$, then every $50 \mathrm{~m}$ from 100 to $250 \mathrm{~m}$. Maximum dive durations were stored from $30 \mathrm{~s}$ to $1 \mathrm{~min}$, then every minute from 1 to $5 \mathrm{~min}$, and finally every $10 \mathrm{~min}$ from 10 to $60 \mathrm{~min}$. In situ temperatures were recorded during dives from 20 to $32^{\circ} \mathrm{C}$, every one degree Celsius.

\subsubsection{CTD-SRDL tags}

The CTD-SRDL tags provided the locations of animals via Argos data, and recorded simplified profiles of the diving parameters (dive depth, time at depth, dive duration and postdive surface interval) and oceanographic data in the form of vertical temperature and salinity profiles taken during the ascent phase of turtle dives (Boehme et al. 2009). The CTD-SRDL tags were programmed to send summarized dive profiles using the compression algorithm described by Fedak et al. (2001), providing four depth records for each dive (instead of the single maximum depth per dive provided by Argos-Fastloc GPS tags). Temperature and salinity data were quality controlled using the procedure described in Roquet et al. (2011), with an estimated accuracy of $0.02{ }^{\circ} \mathrm{C}$ in temperature and 0.05 psu in salinity.

\subsubsection{Prey abundance from trawler}

Over the French Guiana continental shelf, 31 samples of potential olive ridley prey (epifauna) were collected during a survey carried out by IFREMER using a bottom trawler between $15 / 11$ and $20 / 11 / 2014$. The fauna was sampled with a shrimp trawl (1 m vertical opening, $6.7 \mathrm{~m}$ horizontal opening, $45 \mathrm{~mm}$ cod-end mesh size). The trawl hauls were performed on the seafloor at depths of 10 to $60 \mathrm{~m}$. All the individuals collected at each location were identified and counted. As it was not possible to identify the specific species of some individuals, we classified the preys into five groups: cephalopods, crustaceans, cnidarians, molluscs and osteichthyes (fishes).

\subsection{Data pre-filtering}

As the tags were deployed at the beginning of the inter-nesting season, they also recorded locations from the post-nesting migration. Following the procedure described in Chambault et al. (2015), the average daily speed during the inter-nesting season was calculated, a speed filter of $30 \mathrm{~km} \cdot \mathrm{d}^{-1}$ was set, and only the positions associated with a daily speed $>30 \mathrm{~km} \cdot \mathrm{d}^{-1}$ were set to migration phase and then excluded for the analysis. Following the same procedure as Chambault et al. (2015), only the positions corresponding to the internesting season were retained for the analysis.

Using the same approach as Heerah et al. (2013), a Kalman-filtering algorithm was then applied (CLS, Collecte Localisation Satellites, Toulouse, France) to enhance tag position 
estimates (Argos and GPS) by accounting for Argos location errors (Patterson et al. 2010, Lopez et al. 2014). The General Bathymetric Chart of the Oceans database (GEBCO, http://www.gebco.net/, 30-arc-second $1 \mathrm{~km}$ grid) was used to discard any locations on land (13\% and 10\% of the locations recorded in 2013 and 2014, respectively). Positions associated with a speed of over $5 \mathrm{~km} \cdot \mathrm{h}^{-1}$ (2\% in 2013 and 2\% in 2014) (Hays et al. 2004, Schofield et al. 2013) and those with location class $Z$ (class associated with the raw location before Kalman filtering, 1 location recorded in 2013) were considered insufficiently accurate and were removed.

The trackDistance function from the trip package on $\mathrm{R}$ (Luque 2007) was used to calculate the distance travelled and the elapsed time between locations. The observed speed was then derived from these values. The distance to the nesting site, i.e. the location where each turtle was initially tagged, was also calculated for each position.

\subsection{Habitat use}

In order to display the residency patterns, both the Argos and GPS positions were used to estimate the home ranges by mapping the kernel density distributions (Worton 1989). Although GPS locations are much more accurate than Argos locations for the quantification of home ranges (Schofield et al. 2010), we could not base the kernel calculation only on GPS data due to the very low amount of GPS locations transmitted (10\%). To minimize autocorrelation in spatial analyses, median daily locations were generated for each turtle (Schofield et al. 2010, 2013, Revuelta et al. 2015). A kernel density analysis was then designed combining both years of tag deployment using the kernelUD function from adehabitatHR package on $\mathrm{R}$ (Calenge 2006). As the kernel density cannot always be calculated using the least square cross-validation method (Seaman \& Powell 1998), the smoothing parameter $h$ was fixed using the default approach, i.e. the ad hoc method with $h=$ 0.08 (Calenge 2006). Ninety percent contours were used to represent the broad home range, and $50 \%$ density contours were used to define the core area. The corresponding area (expressed in $\mathrm{km}^{2}$ ) was then calculated within each kernel contour.

\subsection{Diving behaviour}

For the diving variables, we discriminated between benthic and pelagic dives by calculating the difference between the bathymetry at the dive location and the maximum dive depth recorded by the CTD-SRDL for the same location for each dive. Therefore, dives with a 
maximum depth within $0 \mathrm{~m}$ of the seabed were classified as benthic dives, and those with a maximum depth above $0 \mathrm{~m}$ of the seabed were pelagic dives. Data from the Argos-linked Fastloc GPS tags $(n=8)$ were not used due to their coarser resolution (one dive depth every $10 \mathrm{~m}$ ). At some locations, depth difference was greater than the bathymetry depth, possibly due to the error generated by the shift between the incorrect Argos positions and the considerable movements of the turtle during the dive or due to GEBCO errors in such coastal habitats.

To obtain an idea of the dive patterns, we calculated the Time of Allocation at Depth (TAD) index by using the four inflection points of the summarized profiles provided by the CTD-SRDL tags. Based on Fedak et al.'s method (2001), TAD calculation makes it possible to obtain relevant information about where turtles concentrate their activity within the dives, i.e. V-shaped dives for $0.5 \leq \mathrm{TAD}<0.75$ (exploratory dives) and U-shaped dives for $0.75 \leq$ TAD $<1$ (activity centered at the bottom of the dive, linked to either foraging or resting activity). Following the method of Plot et al. (2015), the average rate of change of depth was fixed at $1.4 \mathrm{~m} \cdot \mathrm{s}^{-1}$. Bottom time was calculated as the time spent below $80 \%$ of the maximum depth (Heerah et al. 2013), and the descent and ascent rates (in m.s ${ }^{-1}$ ) were also determined.

\subsection{Statistical analyses}

All statistical analyses were performed using R software version 3.2.2 (R Core Team 2015). Before being submitted to statistical tests, all samples were checked for normality and homogeneity of variance by means of the Shapiro-Wilk test. Depending on these results, parametric or nonparametric tests were used, with a significance level of $\alpha=0.05$. Values are means \pm SD

\section{Results}

\subsection{Horizontal movements}

\subsubsection{Capture-mark-recapture data}

During the period from April to September, a total of 1644 gravid female olive ridleys were observed nesting in Remire-Montjoly and Cayenne beaches in 2013 and 1125 gravid females in 2014. The activity peak occurred in July of both years, with 859 nesting events 
recorded in 2013 and 654 in 2014. Nocturnal patrols recorded an average $1.1 \pm 0.3$ and $1.2 \pm 0.4$ nesting events per turtle in 2013 and 2014, respectively (range: 1-4).

\subsubsection{General tracking data}

Among the ten females equipped in 2013, two individuals (\#131354 and \# 131355) started their post-nesting migration directly after the tag deployment, and were therefore discarded from the analyses. In 2014, three turtles (\#130765, \#136776 and \#136778) were also removed from the analyses due to very short tracking duration (3,8 and 4 days, respectively). The data for the horizontal movements of the 14 remaining turtles are summarized in Table 1. On average, 224 \pm 94 locations were recorded per tag, for an average tracking duration ranging from 23 (\#130767 and \#130769) to 54 days (\#130765a and \#136773, Table 1).

The total distance travelled varied from $340 \mathrm{~km}$ (\#130767) to $1094 \mathrm{~km}$ (\#130771), for an average distance of $607 \pm 237.6 \mathrm{~km}$ (Table 1). The average travel speed was $1.1 \pm 0.1 \mathrm{~km} . \mathrm{h}^{-}$ ${ }^{1}$ (range: $0.9 \pm 0.8 \mathrm{~km} \cdot \mathrm{h}^{-1} \# 136772$ vs. $1.4 \pm 1.2 \mathrm{~km} \cdot \mathrm{h}^{-1} \# 130771$ ). The distance travelled differed significantly among individuals in 2013 (Kruskal-Wallis rank sum test: $\chi^{2}=16.7$, df $=7, p<0.05$ ), but not in 2014 (Kruskal-Wallis rank sum test: $\chi^{2}=2.7$, df $=8, p=0.95$ ). In 2013, the daily speed ranged from $16.9 \pm 9.6 \mathrm{~km} \cdot \mathrm{d}^{-1}$ (\#136770) to $24.4 \pm 11.3 \mathrm{~km} \cdot \mathrm{d}^{-1}$ (\#130771), for an average daily speed of $20.1 \pm 10.6 \mathrm{~km} . \mathrm{d}^{-1}$. In 2014, the daily speed ranged from $16.6 \pm 9.9$ $\mathrm{km} \cdot \mathrm{d}^{-1}$ (\#136779) to $23.8 \pm 21.8 \mathrm{~km} \cdot \mathrm{d}^{-1}$ (\#130776), for an average daily speed of $17.6 \pm 10.7$ $\mathrm{km} \cdot \mathrm{d}^{-1}$. Similarly, the daily speeds also differed significantly among individuals in 2013 but not in 2014 (2013: Kruskal Wallis rank sum test, $\chi^{2}=14.6$, df $=7, p<0.01 ; 2014: \chi^{2}=2.7$, df $=8, p=0.95$, respectively).

Table 1. Summary of the horizontal movements of the olive ridleys equipped in 2013 and 2014. PTT refers to the turtle ID, and Nloc to the number of locations recorded.

\begin{tabular}{|c|c|c|c|c|c|c|c|}
\hline PTT & Instrument & $\begin{array}{l}\text { Start } \\
\text { date }\end{array}$ & $\begin{array}{l}\text { Migration } \\
\text { start }\end{array}$ & Nloc & $\begin{array}{c}\text { Tracking } \\
\text { duration (d) }\end{array}$ & $\begin{array}{c}\text { Distance } \\
\text { travelled } \\
(\mathbf{k m})\end{array}$ & $\begin{array}{c}\text { Speed } \\
\left(\mathrm{km}^{\left.-h^{-1}\right)}\right.\end{array}$ \\
\hline $130764 a$ & MK10 & $27 / 06 / 13$ & $22 / 07 / 13$ & 183 & 25 & 387 & $1.1 \pm 0.9$ \\
\hline $130765 a$ & MK10 & $26 / 06 / 13$ & $19 / 08 / 13$ & 457 & 54 & 930 & $1.1 \pm 1.0$ \\
\hline 130766 & MK10 & $27 / 06 / 13$ & 06/08/13 & 282 & 40 & 778 & $1.2 \pm 1.1$ \\
\hline 130767 & MK10 & 28/06/13 & $21 / 07 / 13$ & 159 & 23 & 340 & $0.9 \pm 1.1$ \\
\hline 130768 & MK10 & $27 / 06 / 13$ & 03/08/13 & 246 & 37 & 836 & $1.3 \pm 1.0$ \\
\hline 130769 & MK10 & $27 / 06 / 13$ & $20 / 07 / 13$ & 103 & 23 & 390 & $1.3 \pm 1.1$ \\
\hline 130770 & MK10 & 28/06/13 & $04 / 08 / 13$ & 258 & 37 & 526 & $1.1 \pm 1.0$ \\
\hline 130771 & MK10 & $27 / 06 / 13$ & 08/08/13 & 340 & 42 & 1094 & $1,3 \pm 1.1$ \\
\hline 130764 & CTD-SRDL & $29 / 07 / 14$ & $27 / 08 / 14$ & 190 & 29 & 543 & $1.1 \pm 1.0$ \\
\hline
\end{tabular}




$\begin{array}{llllccrr}136772 & \text { CTD-SRDL } & 25 / 07 / 14 & 20 / 08 / 14 & 115 & 26 & 342 & 0.8 \pm 0.8 \\ 136773 & \text { CTD-SRDL } & 29 / 07 / 14 & 21 / 09 / 14 & 204 & 54 & 798 & 1.1 \pm 1.0 \\ 136774 & \text { CTD-SRDL } & 30 / 07 / 14 & 28 / 08 / 14 & 142 & 29 & 506 & 1.3 \pm 1.3 \\ 136777 & \text { CTD-SRDL } & 30 / 07 / 14 & 28 / 08 / 14 & 179 & 29 & 514 & 1.0 \pm 1.0 \\ 136779 & \text { CTD-SRDL } & 25 / 07 / 14 & 29 / 08 / 14 & 153 & 35 & 517 & 1.0 \pm 1.0 \\ & & & & \mathbf{2 2 4} \pm \mathbf{9 4} & \mathbf{3 5} \pm \mathbf{1 0 . 3} & \mathbf{6 0 7} \pm \mathbf{2 3 7 . 6} & \mathbf{1 . 1} \pm \mathbf{0 . 1}\end{array}$

\subsubsection{Distance to the nesting beach}

The distance to the nesting beach varied over the inter-nesting period. Although the turtles moved farther away in 2013 compared to 2014 (up to 38 km vs. 19 km, Figures 1 and 2A), the same pattern was observed for both years: a sharp increase was observed in the distance to the nesting site during the first half of the tracking (2013: $29.7 \pm 28.7 \mathrm{~km}$ vs. 2014 : $25.6 \pm 24.1 \mathrm{~km}$ ), followed by a decrease with turtles remaining within $9 \mathrm{~km}$ of the nesting beach (Figure 1). During the second phase of the nesting season, the turtles remained an average $8.5 \pm 10.4 \mathrm{~km}$ from the beach in 2013 , and up to $8.8 \pm 10.9 \mathrm{~km}$ in 2014 . However, the distance to the nesting beach varied among individuals for each year (2013: Kruskal-Wallis rank sum test, $\chi^{2}=89, \mathrm{df}=7, p<0.001 ; 2014$ : Kruskal-Wallis rank sum test, $\chi^{2}=90$, df $=8$, $p<0.001)$.

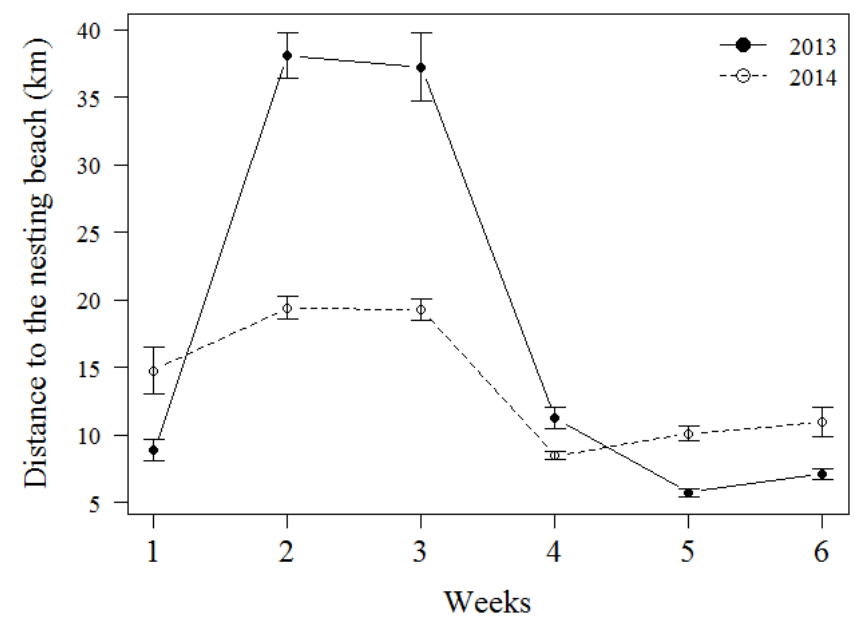

Figure 1. Distance to the nesting beach in 2013 (filled dots) and 2014 (open dots) over the weeks during the inter-nesting season.

\subsubsection{Home range}

There was an inter-annual variability regarding the core home range (50\% kernel estimator) used by the turtles: the core home range covered $161 \mathrm{~km}^{2}$ in 2013 , compared to 309 $\mathrm{km}^{2}$ in 2014. In contrast, the broad home range (90\% kernel estimator) was similar for both years, covering $1401 \mathrm{~km}^{2}$ in 2013, and $1490 \mathrm{~km}^{2}$ in 2014 (Figure 2B). The total home range 
for both years of tag deployment extends over $2813 \mathrm{~km}^{2}$, and the turtles centred their activity (50\% kernel contours) within a $409 \mathrm{~km}^{2}$ area.

Figure 2. (A) Locations of the 14 olive ridleys tracked in 2013 (black dots) and 2014 (grey dots) and (B) kernel contours (90\% shown in turquoise and 50\% shown in dark blue) of the 14 olive ridleys tracked in 2013 and 2014. French Guiana is highlighted in red in B. FG stands for French Guiana, S for Suriname and B for Brazil.

A

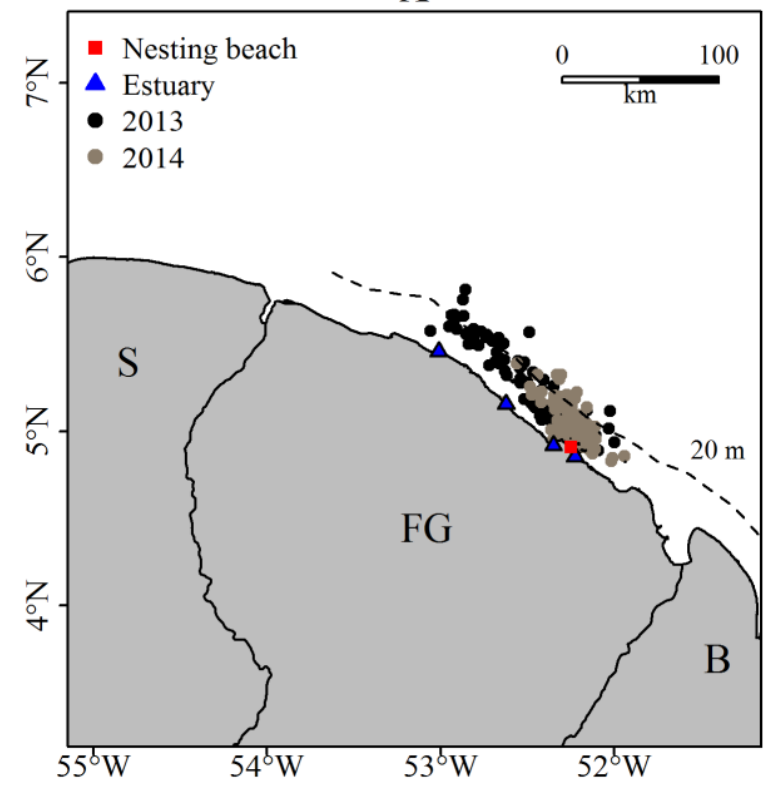

B

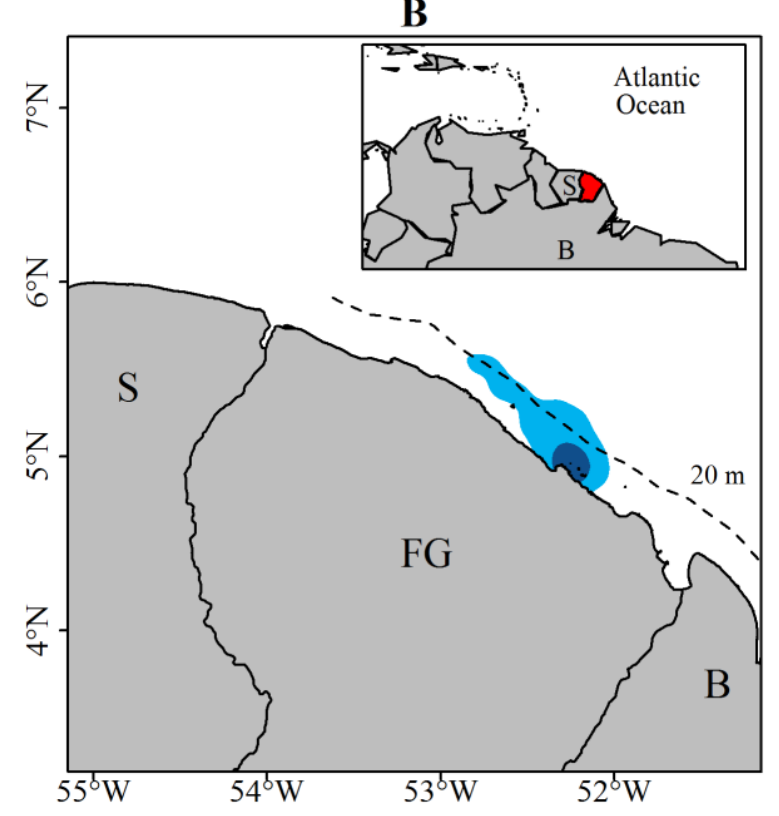

\subsection{Vertical movements}




\subsubsection{Maximum depth, dive duration and surface interval}

Among the 20 tags deployed in $2013(n=10)$ and $2014(n=10), 14$ were retained for the diving behaviour analyses, providing a total of 4527 dive records, or an average of $397 \pm 372$ records per turtle.

\subsubsection{Argos-linked Fastloc GPS tags}

In 2013, the maximum dive depth differed significantly between individuals (KruskalWallis rank sum test: $\chi^{2}=316, \mathrm{df}=7, p<0.001$ ), and ranged from 0 to $50 \mathrm{~m}$ (mean: $12.6 \pm 6.7$ $\mathrm{m}$ ), with $82 \%$ of the dives performed in the upper $10 \mathrm{~m}$ (Figure 3A). Dive durations differed significantly between individuals (Kruskal-Wallis rank sum test: $\chi^{2}=206, \mathrm{df}=7, p<0.001$ ) and ranged from 0-70 min (mean: $30.6 \pm 19.8 \mathrm{~min}$ ), with $44 \%$ of the dives lasting up to $20 \mathrm{~min}$ (Figure 3B).

\subsubsection{CTD-SRDL tags}

In 2014, the maximum dive depth differed significantly between individuals (KruskalWallis rank sum test: $\chi^{2}=47, \mathrm{df}=8, p<0.001$ ), and ranged from 0 to $35 \mathrm{~m}$ (mean: $5.8 \pm 4.6$ $\mathrm{m}$ ), with $90 \%$ of the dives performed in the upper $10 \mathrm{~m}$ (Figure 3C).

Dive durations differed significantly between individuals (Kruskal-Wallis rank sum test: $\chi^{2}=26, \mathrm{df}=8, p<0.001$ ) and ranged from 0-95 min (mean: $9.1 \pm 13.7 \mathrm{~min}$ ), with $76 \%$ of the dives lasting up to 10 min (Figure 3D).

Post-dive surface interval ranged from $0.06 \mathrm{sec}$ to $9 \mathrm{~min}$, for an average duration of $63.2 \pm 12.2 \mathrm{sec}$. Eighty-seven percent of the post-dive surface intervals lasted less than $2 \mathrm{~min}$, and differed significantly between individuals (Kruskal-Wallis rank sum test: $\chi^{2}=60, \mathrm{df}=8$, $p<0.001$, Figure 3E). 
A

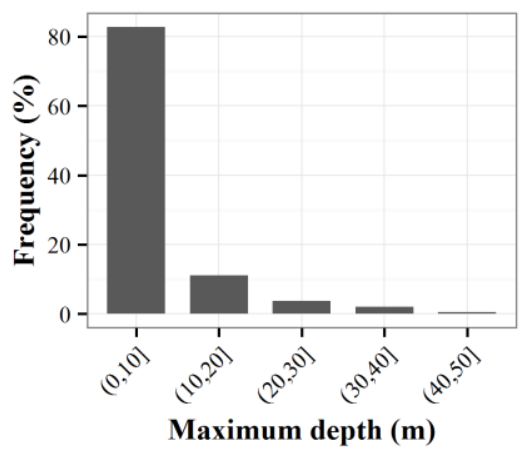

C

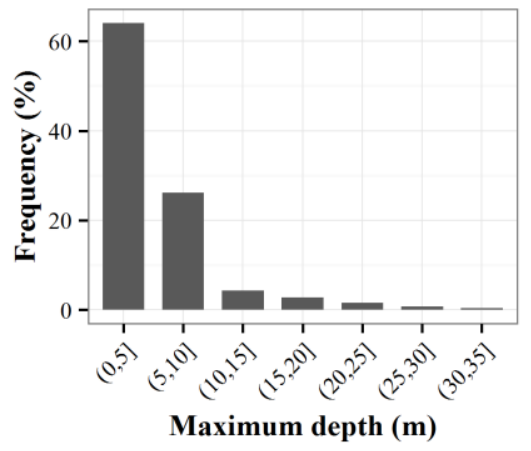

B

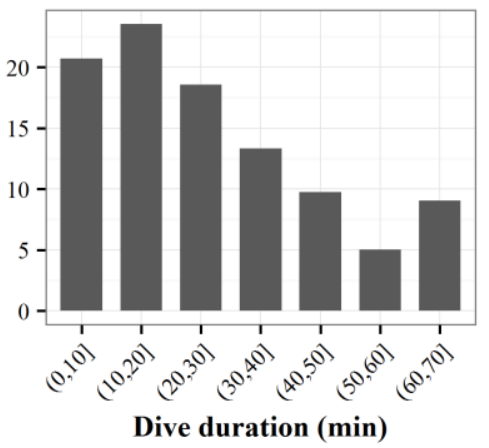

D

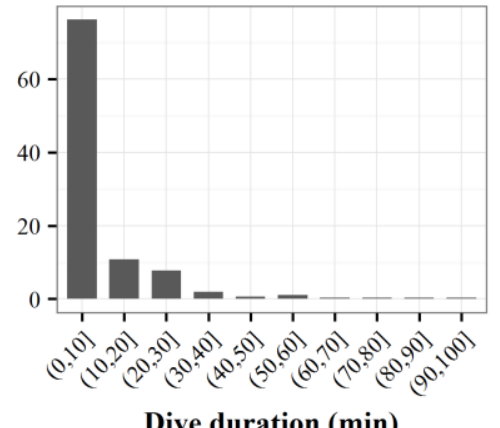

Dive duration ( $\min )$
$\mathbf{E}$

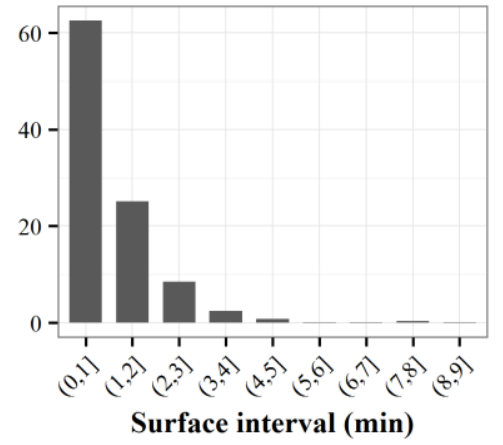

Figure 3. Histograms of the diving variables recorded by the Argos-linked Fastloc GPS tags (A and $\mathrm{B}$ ) and the CTD-SRDL tags (C, D and E): maximum dive depth (A and C), dive duration (B and $\mathrm{D})$, and post-dive surface interval (E) for all individuals.

\subsubsection{Dive shape}

Eighty-one percent of the dives performed by the turtles tracked in 2014 were benthic dives, and $19 \%$ were pelagic dives. The average TAD was $0.76 \pm 0.13$, indicating mainly Ushaped dives. Fifty-seven percent of the dives were associated with a TAD ranging between $0.75 \leq \mathrm{TAD}<0.1$ (resting U-shaped dives), and $38 \%$ were associated with a TAD between $0.5 \leq \mathrm{TAD}<0.75$ (exploratory $\mathrm{V}$-shaped dives).

$\mathrm{V}$-shaped dives were predominant at the beginning of the tracking period, then decreased over the weeks (Figure 4). Inversely, the U-shaped benthic dives increased over the period, increasing from $32 \%$ to $73 \%$ of the total weekly dives recorded. The U-shaped pelagic dives were the less abundant type of dives and only occurred from week 2 to week 5. 


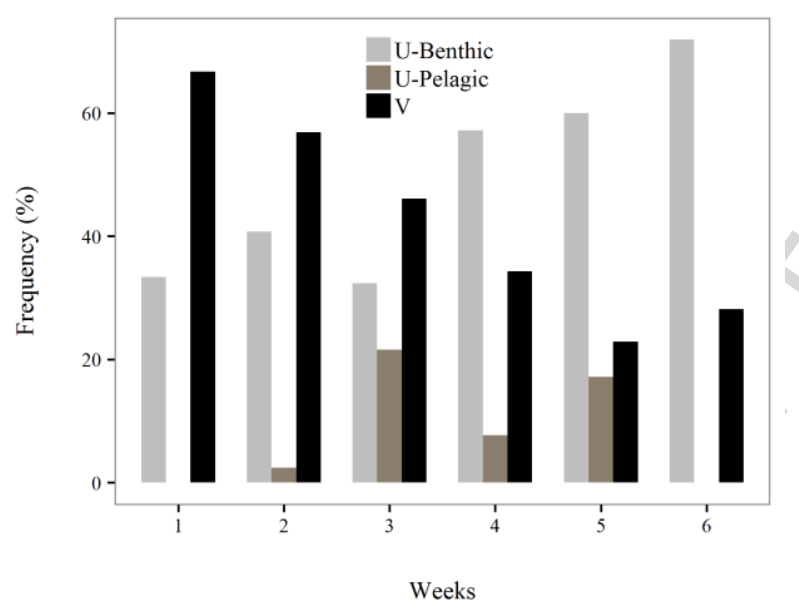

Figure 4. Bar plots of the dive shape over weeks recorded by the six CTD-SRDL tags in 2014

\subsubsection{Diving behavioural shifts over the inter-nesting season}

The diving behaviour varied over the inter-nesting season. Although the turtles dived deeper and for longer durations in 2013 compared to 2014 (up to $17.5 \mathrm{~m}$ vs. $12.6 \mathrm{~m}$; up to $42.9 \mathrm{~min}$ vs. $32.9 \mathrm{~min}$ ), the same pattern was observed for both years, with deeper and longer dives during the first three weeks of tracking for 2013 and the first two weeks for 2014, followed by shallower and shorter dives for the rest of the inter-nesting season (Figure 5A and B). The post-dive surface interval recorded in 2014 followed the same pattern (Figure 5C).
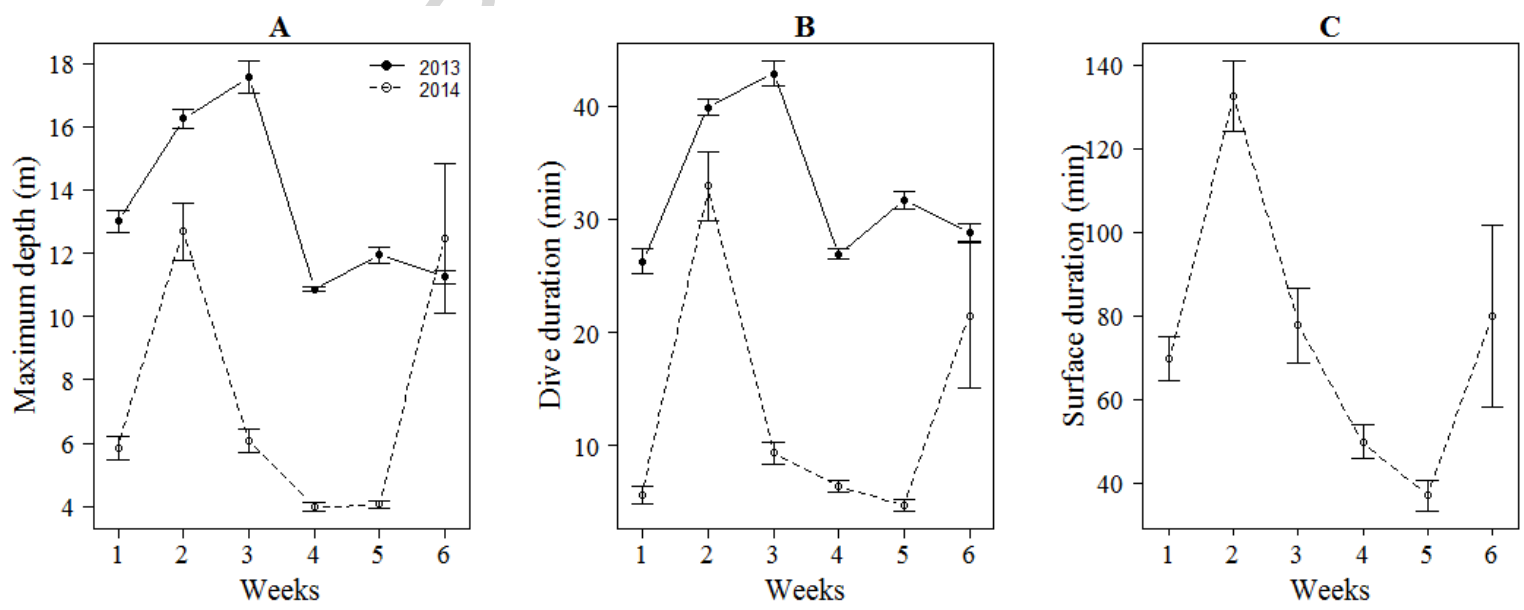

Figure 5. Average diving variables (+SD) recorded in 2013 (filled dots) and 2014 (open dots) over the weeks of the inter-nesting season. (A) Maximum depth, (B) dive duration and (C) post-dive surface interval. 


\subsubsection{Habitat characterization}

\subsubsection{Potential preys collected from the trawler}

The data for prey sampled by the trawler (IFREMER French Guiana) between 15/11 and 20/11/2014 provided 31 records from depths of 12-51.8m along the French Guiana coast. During the sampling period, a total of 8730 organisms belonging to five different groups were collected: crustaceans $(n=4489)$, osteichthyes (fish, $n=3063)$, molluscs $(n=976)$, cephalopods $(n=162)$ and cnidarians $(n=17)$. Over the 31 samplings, the crustacean group was the most abundant, representing $51 \%$ of the samples, followed by the osteichthye group (35\%). Seven samples were collected within the 90\% kernel contour of 2014 (Figure 3A), and mainly contained two highly abundant groups: crustaceans (42\%) and osteichthyes (39\%) see Figure 6B.

A

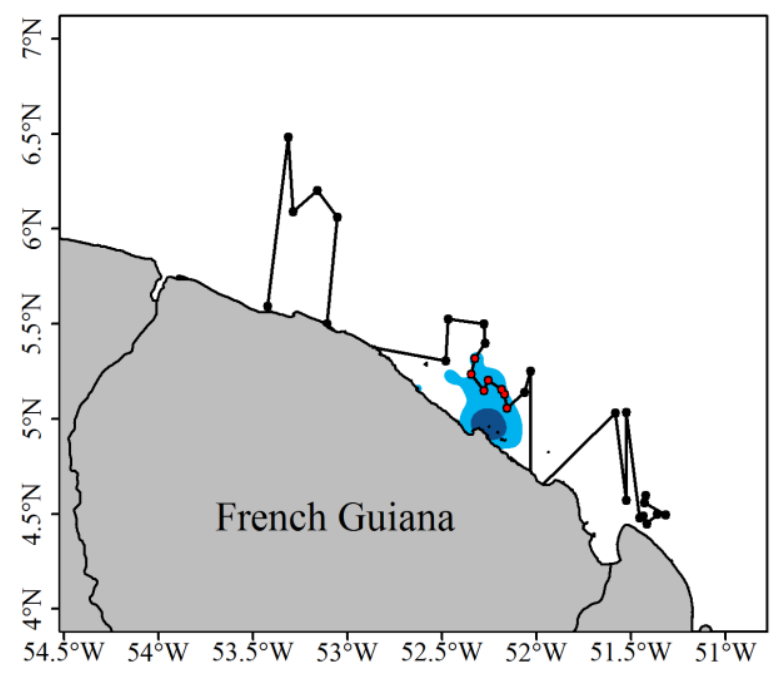

B

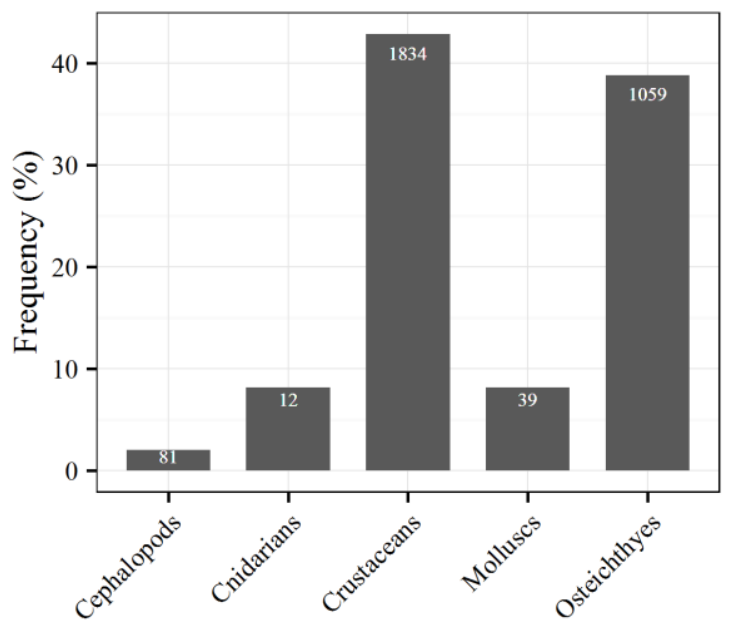

Figure 6. (A) Trawler transect in relation to the kernel densities for 2014 (90\% shown in turquoise and 50\% shown in dark blue). (B) Percentage of individuals sampled for each prey group within the $90 \%$ home range in 2014 (shown by red dots in A). The white numbers in B refer to the individual abundance sampled within each group.

\subsubsection{Oceanographic data recorded by the tags}

In 2013, the Argos-Linked Fastloc GPS tags recorded 1224 temperature values, ranging from 26 to $33^{\circ} \mathrm{C}$, for an average temperature of $28.3 \pm 1{ }^{\circ} \mathrm{C}$ (Figure $7 \mathrm{~A}$ ). Seventy-six percent of the dives were performed in warm waters with temperatures between 27 and $29{ }^{\circ} \mathrm{C}$.

In 2014, the CTD-SRDL tags recorded 91 temperature values, ranging from 26.1 and $28.1{ }^{\circ} \mathrm{C}$ (mean: $26.7 \pm 0.4{ }^{\circ} \mathrm{C}$ ), and 84 salinity values, ranging from 19.5 to 36.4 psu (mean: 
32.8 \pm 5 psu) - see Figure 7B. All turtles had used a broad range of oceanographic structures, crossing three different density patches.

A

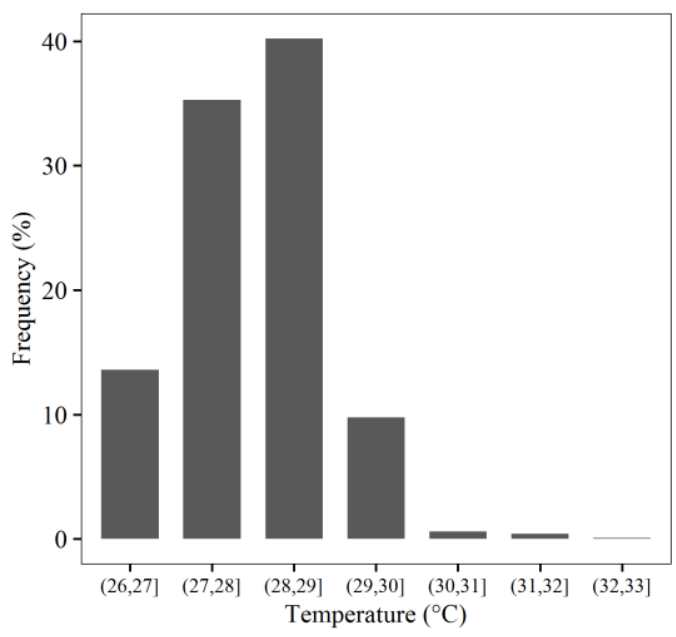

B

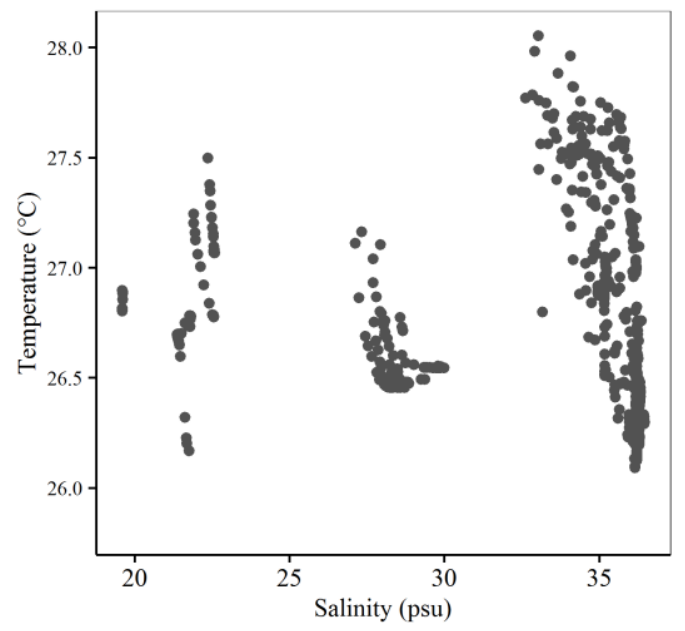

Figure 7. (A) Histogram of the temperatures recorded by the Argos-linked Fastloc GPS tags in 2013, and (B) Temperature-Salinity diagram from the CTD-SRDL tags deployed in 2014.

\section{Discussion}

The tracking of these 20 gravid olive ridleys over the French Guiana continental shelf provides crucial information about (i) their habitat use and (ii) behavioural shifts that occur during the energetically costly inter-nesting season.

\subsection{Habitat use}

The kernel analysis indicated that the turtles spent most of their time in a relatively small area, covering $409 \mathrm{~km}^{2}$ (50\%). To date, the literature on the home range of this species is very limited, and only one study conducted in Central Africa has described a core range used by olive ridleys, covering $1267 \mathrm{~km}^{2}$ (Maxwell et al. 2011), being bigger than in the present study $\left(409 \mathrm{~km}^{2}\right)$. Such difference might be due to the different method used to calculate the home range (Minimum Convex Polygon vs. kernel densities) and also to the core range definition, as in Central Africa it was defined as $80 \%$ vs. $50 \%$ in our study. Turtle movements were close to the shore, generally not crossing the $20 \mathrm{~m}$ isobaths and remaining in shallower waters than those previously observed in other olive ridley populations, which usually occupy waters with depths of up to $50 \mathrm{~m}$ (Whiting et al. 2007, Maxwell et al. 2011, 
Rees et al. 2012). As habitat use is dictated by metabolic rate, such behaviour could therefore reduce the costs of locomotion by limiting their movements (Slavenko et al. 2016). This assumption is reinforced by the low travel speeds found in our study $\left(1.1 \pm 0.1 \mathrm{~km} \cdot \mathrm{h}^{-1}\right)$, compared to those recorded by Chambault et al. $\left(2.5 \pm 0.6 \mathrm{~km} \cdot \mathrm{h}^{-1}, 2016\right)$ during the postnesting migration of the same individuals. The limited displacements were also highlighted by the short distances travelled, with females remaining within $19.6 \pm 23.6 \mathrm{~km}$ from the nesting beach, which is in accordance with the findings of Maxwell et al. (2011) in Central Africa $(27.7 \pm 22.3 \mathrm{~km})$. This behaviour is also identical to that shown by the same olive ridley population during tracking in the inter-nesting season in French Guiana in 2006-2007 $(18.4 \pm 2.9 \mathrm{~km}$, Plot et al. 2012). This site fidelity probably enables turtles to remain in favourable conditions during oviposition, enhancing their fitness. A species which does not provide any parental care will attach great importance to its choice of nesting beach in order to favour the survival of its offspring (Kamel \& Mrosovsky 2005, Péron et al. 2013).

The prey data collected by the trawler (IFREMER, French Guiana) within the $90 \%$ kernel contour has shown the presence of crustaceans (47\%), osteichthyes (26\%), molluscs (17\%), cnidarians (6\%) and cephalopods (4\%). Despite the temporal mismatch between olive ridleys tracking (From June to September) and the trawler sampling (November), the most abundant species found in olive ridleys home range were crustaceans and fish. This species is known to feed mainly on crustaceans and fish during the inter-nesting season, as demonstrated via stomach content analysis in northeast Brazil (Colman et al. 2014). Although no direct evidence of a feeding activity on such animals has been observed in French Guiana to date, the overlapping of potential resources with the distribution of olive ridleys suggests that if olive ridley were foraging during this period, their potential preys that might be available would include mostly crustaceans (47\%) and fish (26\%). Such behaviour would suggest that the turtles may adopt an income breeding strategy to cope with the energy loss that is inherent to reproduction and oviposition. To confirm this assumption, 3D accelerometers and cameras need to be deployed on this species, as previously carried out in green and loggerhead turtles (Fossette et al. 2012, Cheng et al. 2013), and complementary approaches such as isotopic analyses and oesophageal lavages/gut content analysis are also necessary (Hatase et al. 2006, Amorocho \& Reina 2007).

The oceanographic conditions of this habitat were warm (range: $26-33{ }^{\circ} \mathrm{C}$ ) with highly fluctuating waters in terms of salinity (range: 19.5-36.4 psu). The thermal range was close to that experienced by other populations of olive ridleys nesting in Australia (23-29 ${ }^{\circ} \mathrm{C}$, McMahon et al. 2007, Hamel et al. 2008) and Costa Rica (22-28 ${ }^{\circ}$ C, Swimmer et al. 2006). 
However, the turtles crossed environments with varying levels of salinity that ranged from polyhaline (>18 psu) to ultrahaline (>33 psu) depending on their proximity to the shore. The turbid and low salinity waters can be explained by the large discharges coming from the Amazon River plume and other rivers that continuously flow into the French Guiana continental shelf (Jounneau \& Pujos 1988, Froidefond et al. 2002). The neritic domain off the shores of French Guiana is classified into three water classes based on their reflectance, and the olive ridleys concentrated their activity in the green waters (water column depth $<20 \mathrm{~m}$ isobaths) and beige waters (at the river mouths). In the latter, the levels of suspended matter are high ( $\left.115 \mathrm{mg} . \mathrm{l}^{-1}\right)$ and the chlorophyll $a$ concentration is low: $2-3 \mathrm{mg} \cdot \mathrm{m}^{-3}$ (Froidefond et al. 2002). Similar to the Kemp's ridley tracked in the Gulf of Mexico (4.5-36 psu, Metz 2004) and the loggerhead turtles in southwest Florida (0-40 psu, Foley et al. 2006), the olive ridleys nesting in French Guiana show a high tolerance to a wide range of environments.

\subsection{Behavioural shifts over the nesting season}

Multiple behavioural shifts were observed in olive ridleys for both years of tag deployment, and the inter-nesting season could be divided into two phases. The distance to the nesting site increased during the first half of the period (0-21 days: $27.6 \pm 26.4 \mathrm{~km})$, then the turtles remained close to the beach $(8.6 \pm 10.3 \mathrm{~km})$. The satellite tracking of the same olive ridley population followed in 2006 and 2007 indicated similar results (Plot et al. 2012), highlighting a unique reproductive synchrony in this species with individuals moving closer to the nesting beach after 21 days (Plot et al. 2012). These results reinforce the argument for a mass-nesting phenomenon, also called arribadas, which has been evidenced in several olive ridley populations in Mexico, Costa Rica and French Guiana (Eguchi et al. 2007, Plot et al. 2012). In French Guiana and Costa Rica, it has been reported that the inter-nesting interval of this species is approximately 28 days (Plotkin 2007, Plot et al. 2012) and 18 days in Central Africa (Maxwell et al. 2011), which coincides with the moment when the individuals remain close to the nesting beach, i.e. 21 days after the last nesting event, and is probably related to landing synchrony (Plot et al. 2012). However, inter-annual variability has been observed, as the turtles tracked in 2014 moved closer to the nesting beach after only 14 days, indicating possible shorter inter-nesting intervals, as previously observed in other populations (Whiting et al. 2007, Hamel et al. 2008). Such variability in the inter-nesting interval could be explained by the behavioural plasticity of the females during the pre-breeding migration (i.e., a remigration interval that can last from one to two years) and by the different foraging 
grounds used before or during the nesting season (McMahon et al. 2007, Chambault et al. 2016). Indeed, one turtle tracked in 2014 had already been observed in 2013, confirming the uncommon and short remigration interval of this species.

Some behavioural shifts were also observed in diving behaviour, and comprised the same two distinct phases that were identified in the horizontal dimension. Similar to Plot et al. (2012), the turtles performed longer $(33.2 \pm 22.2 \mathrm{~min})$ and deeper dives $(14.2 \pm 8.7 \mathrm{~m})$ during the first half of the inter-nesting season compared to the second half of the tracking $(26.4 \pm 19.4 \mathrm{~min}, 10.6 \pm 5.1 \mathrm{~m})$. These results are consistent with other studies showing that breeding females decrease their dive duration in the few days preceding a nesting event (Hays et al. 1999, Fossette et al. 2007, Houghton et al. 2008, Hamel et al. 2008, Plot et al. 2012), and may be related to the selection of the nesting beach (Plot et al. 2012). At the beginning of the inter-nesting season, such behaviour may indicate either a foraging or a resting activity (Hays et al. 1999, McMahon et al. 2007), especially when turtles perform mostly benthic dives $(92 \%)$. This diving behaviour indicates that they follow the seabed, as previously described in leatherback turtles (Fossette et al. 2007). As olive ridleys performed mainly Vshaped dives $(56 \%)$ during the first three weeks, such a pattern is more likely to be associated with exploratory behaviour. In contrast, the dives were mainly benthic and U-shaped during the second half of the period (63\%), which can be interpreted as either a resting or a foraging activity. Unlike the tracking during the post-nesting migration period, where the dives were mainly pelagic (Chambault et al. 2016), the predominance of benthic dives in the present study excluded the use of hunting time index as a proxy for the foraging behaviour of this species within dives. Further studies therefore need to be conducted at a finer scale using 3D accelerometers on gravid olive ridleys to distinguish between these two activities during the inter-nesting season.

\section{Conservation implications}

The satellite tracking of these French Guianese population of olive ridleys provided crucial information on (i) habitat use and (ii) the behavioural shifts that could be used by these females during the inter-nesting season. The estuarine habitat was confined close to the shore, characterized by turbid waters that were strongly influenced by the river discharges along the Guiana coast (Froidefond et al. 2002). Such conditions make this species critically vulnerable due to reduced visibility (Metz 2004, Chambault et al. 2016) and the high energetic costs of 
reproduction and nesting activities during this period. The strong occurrence of illegal drifting net fisheries in the coastal area of the Guiana shield (Levrel 2012, Cissé et al. 2014) exposes this vulnerable species to lethal interactions via bycatch (DEAL Guyane \& Agence des Aires Marines Protégées 2013). This situation requires the implementation of highly coercive but geographically localized measures in this small area $\left(409 \mathrm{~km}^{2}\right)$ used by breeding turtles. A further investigation on the interactions between olive ridleys and fisheries is therefore needed to support the application of adequate measures to ensure the conservation of this threatened species.

\section{Acknowledgements}

This study was carried out within the framework of the Plan National d'Action Tortues Marines de Guyane and was produced as part of the CARET2 cooperation project between French Guiana and Suriname, headed by the French Guiana office of WWF-France, in partnership with Kwata NGO, the French National Agency for Hunting and Wildlife (ONCFS), the French Guiana Regional Nature Park (PNRG) and WWF Guianas. The CARET2 program was co-financed by the OP Amazonia with the European Union, the Fondation EDF, the Fondation de France, the Ministry of Ecology, Sustainable Development and Energy, and the French National Centre for Space Studies (CNES). It was also supported by the French Guiana Regional Council. PC was supported by Shell and CNES Guyane. The trawl survey carried out by IFREMER was funded within the STUDY program supported by Shell and the European Operational Program FEDER (European funds for the region development) in French Guiana. The authors also appreciate the support of the ANTIDOT project (Pépinière Interdisciplinaire de Guyane, Mission pour l'Interdisciplinarité, CNRS). We would like to thank Anne Corval (CNRS Guyane), Hélène Delvaux (DEAL Guyane) and Eric Hansen (ONCFS DIROM) for their strong support and help in developing this project. 


\section{References}

Amorocho D, Reina R (2007) Feeding ecology of the East Pacific green sea turtle Chelonia mydas agassizii at Gorgona National Park, Colombia. Endanger Species Res 3:43-51

Baudouin M, De Thoisy B, Chambault P, Berzins R, Entraygues M, Kelle L, Turny A, Le Maho Y, Chevallier D (2015) Identification of key marine areas for conservation based on satellite tracking of post-nesting migrating green turtles (Chelonia mydas). Biol Conserv 184:36-41

Blanco GS, Morreale SJ, Seminoff JA, Paladino FV, Piedra R, Spotila JR (2013) Movements and diving behavior of internesting green turtles along Pacific Costa Rica. Integr Zool 8:293-306

Boehme L, Lovell P, Biuw M, Roquet F, Nicholson J, Thorpe S, Meredith M, Fedak M (2009) Technical Note: Animal-borne CTD-Satellite Relay Data Loggers for realtime oceanographic data collection. Ocean Sci:685-695

Calenge C (2006) The package adehabitat for the R software: a tool for the analysis of space and habitat use by animals. Ecol Model 197:516-519

Chambault P, De Thoisy B, Heerah K, Conchon A, Barrioz S, Dos Reis V, Berzins R, Kelle L, Picard B, Roquet F, Le Maho Y, Chevallier D (2016) The influence of oceanographic features on the foraging behavior of the olive ridley sea turtle Lepidochelys olivacea along the Guiana coast. Prog Oceanogr 142:58-71

Chambault P, De Thoisy B, Kelle L, Berzins R, Bonola M, Delvaux H, Le Maho Y, Chevallier D (2016) Inter-nesting behavioural adjustments of green turtles to an estuarine habitat in French Guiana. Mar Ecol Prog Ser

Chambault P, Pinaud D, Vantrepotte V, Kelle L, Entraygues M, Guinet C, Berzins R, Bilo K, Gaspar P, De Thoisy B, Le Maho Y, Chevallier D (2015) Dispersal and diving adjustments of the green turtle Chelonia mydas in response to dynamic environmental conditions during post-nesting migration. PLoS ONE 10

Cheng I, Bentivegna F, Hochscheid S (2013) The behavioural choices of green turtles nesting at two environmentally different islands in Taiwan. J Exp Mar Biol Ecol 440:141-148

Cissé AA, Blanchard F, Guyader 0 (2014) Sustainability of tropical small-scale fisheries: Integrated assessment in French Guiana. Mar Policy 44:397-405

Colman LP, Sampaio CLS, Weber MI, Castilhos JC de (2014) Diet of Olive Ridley Sea Turtles, Lepidochelys olivacea, in the Waters of Sergipe, Brazil. Chelonian Conserv Biol 13:266-271

DEAL Guyane, Agence des Aires Marines Protégées (2013) Analyse Stratégique Régionale Guyane: Enjeux et propositions de création d'aires marines protégées. 
DeMaster D, Smith W, Nelson D, Aller J (1996) Biogeochemical processes in Amazon shelf waters: chemical distributions and uptake rates of silicon, carbon and nitrogen. Cont Shelf Res 16:617-643

Drent R, Daan S (1980) The prudent parent: adjustments in avian breeding. Ardea 68:225-252

Eguchi T, Gerrodette T, Pitman RL, Seminoff JA, Dutton PH (2007) At-sea density and abundance estimates of the olive ridley turtle Lepidochelys olivacea in the eastern tropical Pacific. Endanger Species Res 3:191-203

Fedak MA, Lovell P, Grant SM (2001) Two Approaches to Compressing and Interpreting Time-Depth Information as Collected by Time-Depth Recorders and SatelliteLinked Data Recorders. Mar Mammal Sci 17:94-110

Foley AM, Peck SA, Harman GR (2006) Effects of Sand Characteristics and Inundation on the Hatching Success of Loggerhead Sea Turtle (Caretta caretta) Clutches on LowRelief Mangrove Islands in Southwest Florida. Chelonian Conserv Biol 5:32-41

Fossette S, Georges JY, Tanaka H, Ropert-Coudert Y, Ferraroli S, Arai N, Sato K, Naito Y, Maho YL (2007) Dispersal and dive patterns in gravid leatherback turtles during the nesting season in French Guiana. Mar Ecol Prog Ser 338:233-247

Fossette S, Schofield G, Lilley MKS, Gleiss AC, Hays GC (2012) Acceleration data reveal the energy management strategy of a marine ectotherm during reproduction. Funct Ecol 26:324-333

Froidefond J-M, Gardel L, Guiral D, Parra M, Ternon J-F (2002) Spectral remote sensing reflectances of coastal waters in French Guiana under the Amazon influence. Remote Sens Environ 80:225-232

Godfrey M, Godley BJ (2008) Seeing past the red: flawed IUCN global listings for sea turtles. Endanger Species Res 6:155-159

Guéguen F (2000) Distribution et abondance des poissons démersaux et de quelques autres organismes benthiques marins du plateau continental (0-60 m) de Guyane française. Comptes Rendus Académie Sci - Ser III - Sci Vie 323:775-791

Hamel MA, McMahon CR, Bradshaw CJA (2008) Flexible inter-nesting behaviour of generalist olive ridley turtles in Australia. J Exp Mar Biol Ecol 359:47-54

Hart KM, Sartain AR, Fujisaki I, Jr HLP, Morley D, Feeley MW (2012) Home range, habitat use, and migrations of hawksbill turtles tracked from Dry Tortugas National Park, Florida, USA. Mar Ecol Prog Ser 457:193-207

Hart KM, Zawada DG, Fujisaki I, Lidz BH (2010) Inter-nesting habitat-use patterns of loggerhead sea turtles: enhancing satellite tracking with benthic mapping. Aquat Biol 11:77-90 
Hart KM, Zawada DG, Fujisaki I, Lidz BH (2013) Habitat use of breeding green turtles Chelonia mydas tagged in Dry Tortugas National Park: Making use of local and regional MPAs. Biol Conserv 161:142-154

Hatase H, Sato K, Yamaguchi M, Takahashi K, Tsukamoto K (2006) Individual variation in feeding habitat use by adult female green sea turtles (Chelonia mydas): are they obligately neritic herbivores? Oecologia 149:52-64

Hays GC, Luschi P, Papi F, Del SC, Marsh R (1999) Changes in behaviour during the internesting period and post-nesting migration for Ascension Island green turtles. Mar Ecol Prog Ser 189:263-273

Hays GC, Mazaris AD, Schofield G (2014) Different male vs. female breeding periodicity helps mitigate offspring sex ratio skews in sea turtles. Front Mar Sci 1

Hays GC, Metcalfe JD, Walne AW, Wilson RP (2004) First records of flipper beat frequency during sea turtle diving. J Exp Mar Biol Ecol 303:243-260

Heerah K, Andrews-Goff V, Williams G, Sultan E, Hindell M, Patterson T, Charrassin J-B (2013) Ecology of Weddell seals during winter: Influence of environmental parameters on their foraging behaviour. Deep Sea Res Part II Top Stud Oceanogr 88-89:23-33

Houghton JDR, Cedras A, Myers AE, Liebsch N, Metcalfe JD, Mortimer JA, Hays GC (2008) Measuring the state of consciousness in a free-living diving sea turtle. J Exp Mar Biol Ecol 356:115-120

Jounneau JM, Pujos M (1988) Suspended matter and bottom deposits in the Maroni estuarine system (French Guiana). Neth J Sea Res 22:99-108

Kamel SJ, Mrosovsky N (2005) Repeatability of nesting preferences in the hawksbill sea turtle, Eretmochelys imbricata, and their fitness consequences. Anim Behav 70:819-828

Kelle L, Gratiot N, De Thoisy B (2009) Olive ridley turtle Lepidochelys olivacea in French Guiana: back from the brink of regional extirpation? Oryx 43:243-246

Levrel A (2012) Estimation de la pêche illégale étrangère en Guyane Française. IFREMER

Lopez R, Malarde J-P, Royer F, Gaspar P (2014) Improving Argos Doppler Location Using Multiple-Model Kalman Filtering. IEEE Trans Geosci Remote Sens 52:4744-4755

Luque S (2007) Diving Behaviour Analysis in R. R News 7:8-14

Marcovaldi M, Lopez GG, Soares L, Lopez-Mendilaharsu M (2012) Satellite tracking of hawksbill turtles Eretmochelys imbricata nesting in northern Bahia, Brazil: turtle movements and foraging destinations. Endanger Species Res 17:123-132

Maxwell SM, Breed GA, Nickel BA, Makanga-Bahouna J, Pemo-Makaya E, Parnell RJ, Formia A, Ngouessono S, Godley BJ, Costa DP, Witt MJ, Coyne MS (2011) Using 
Satellite Tracking to Optimize Protection of Long-Lived Marine Species: Olive Ridley Sea Turtle Conservation in Central Africa. PLoS ONE 6:e19905

McMahon C, Bradshaw C, Hays G (2007) Satellite tracking reveals unusual diving characteristics for a marine reptile, the olive ridley turtle Lepidochelys olivacea. Mar Ecol Prog Ser 329:239-252

Metz TL (2004) Factors influencing Kemp's ridley sea turtle (Lepidochelys kempii) distribution in nearshore waters and implications for management. Texas A\&M University

Miller JD (1997) Reproduction in sea turtles. In: The biology of sea turtles (P.L. Lutz and J.A. Musick, eds.), CRC Press, Boca Raton, FL.p 51-81

Milliman J, Meade R (1983) World-wide delivery of river sediment to the ocean. J Geol 91

Patterson TA, McConnell BJ, Fedak MA, Bravington MV, Hindell MA (2010) Using GPS data to evaluate the accuracy of state-space methods for correction of Argos satellite telemetry error. Ecology 91:273-285

Pendoley KL, Schofield G, Whittock PA, Ierodiaconou D, Hays GC (2014) Protected species use of a coastal marine migratory corridor connecting marine protected areas. Mar Biol 161:1455-1466

Péron C, Chevalier C, Galpin M, Chatelet A, Anthony EJ, Le Maho Y, Gardel A (2013) Beach morphological changes in response to marine turtles nesting: a preliminary study of Awala-Yalimapo beach, French Guiana (South America). J Coast Res 65

Pikesley SK, Maxwell SM, Pendoley K, Costa DP, Coyne MS, Formia A, Godley BJ, Klein W, Makanga-Bahouna J, Maruca S, Ngouessono S, Parnell RJ, Pemo-Makaya E, Witt MJ (2013) On the front line: integrated habitat mapping for olive ridley sea turtles in the southeast Atlantic. Divers Distrib 19:1518-1530

Plot V, De Thoisy B, Blanc S, Kelle L, Lavergne A, Roger-Bérubet H, Tremblay Y, Fossette S, Georges J-Y (2012) Reproductive synchrony in a recovering bottlenecked sea turtle population. J Anim Ecol 81:341-351

Plot V, De Thoisy B, Georges J (2015) Dispersal and dive patterns during the postnesting migration of olive ridley turtles from French Guiana. Endanger Species Res 26:221-234

Plotkin PT (2007) Biology and Conservation of Ridley Sea Turtles. JHU Press

Plotkin P (2010) Nomadic behaviour of the highly migratory olive ridley sea turtle Lepidochelys olivacea in the eastern tropical Pacific Ocean. Endanger Species Res 13:33-40

Polovina JJ, Balazs GH, Howell EA, Parker DM, Seki MP, Dutton PH (2004) Forage and migration habitat of loggerhead (Caretta caretta) and olive ridley (Lepidochelys olivacea) sea turtles in the central North Pacific Ocean. Fish Oceanogr 13:36-51 
R Core Team (2015) R: A language and environment for statistical computing. $R$ Foundation for Statistical Computing, Vienna, Austria. URL http://www.Rproject.org/.

Rees A, Broderick A, Papathanasopoulou N, Godley B (2012) Conservation related insights into the behaviour of the olive ridley sea turtle Lepidochelys olivacea nesting in Oman. Mar Ecol Prog Ser 450:195-205

Reis EC, Moura JF de, Lima LM, Rennó B, Siciliano S (2010) Evidence of migratory movements of olive ridley turtles (Lepidochelys olivacea) along the Brazilian coast. Braz J Oceanogr 58:255-259

Revuelta O, Hawkes L, León M, Godley BJ, Raga JA, Tomás J (2015) Evaluating the importance of Marine Protected Areas for the conservation of hawksbill turtles Eretmochelys imbricata nesting in the Dominican Republic. Endanger Species Res 27:169-180

Richardson PB, Broderick AC, Coyne MS, Ekanayake L, Kapurusinghe T, Premakumara C, Ranger S, Saman MM, Witt MJ, Godley BJ (2013) Satellite telemetry reveals behavioural plasticity in a green turtle population nesting in Sri Lanka. Mar Biol 160:1415-1426

Roquet F, Charrassin J-B, Marchand S, Boehme L, Fedak M, Reverdin G, Guinet C (2011) Delayed-Mode Calibration of Hydrographic Data Obtained from Animal-Borne Satellite Relay Data Loggers. J Atmospheric Ocean Technol 28:787-801

Schofield G, Hobson VJ, Lilley MKS, Katselidis KA, Bishop CM, Brown P, Hays GC (2010) Inter-annual variability in the home range of breeding turtles: Implications for current and future conservation management. Biol Conserv 143:722-730

Schofield G, Scott R, Dimadi A, Fossette S, Katselidis KA, Koutsoubas D, Lilley MKS, Pantis JD, Karagouni AD, Hays GC (2013) Evidence-based marine protected area planning for a highly mobile endangered marine vertebrate. Biol Conserv 161:101-109

Scott R, Hodgson DJ, Witt MJ, Coyne MS, Adnyana W, Blumenthal JM, Broderick AC, Canbolat AF, Catry P, Ciccione S, Delcroix E, Hitipeuw C, Luschi P, Pet-Soede L, Pendoley K, Richardson PB, Rees AF, Godley BJ (2012) Global analysis of satellite tracking data shows that adult green turtles are significantly aggregated in Marine Protected Areas. Glob Ecol Biogeogr 21:1053-1061

Seaman DE, Powell RA (1998) Kernel home range estimation program (kernelhr). Doc Program

Seney EE, Landry AM Movements of Kemp's ridley sea turtles nesting on the upper Texas coast: implications for management. Endanger Species Res 4:73-84

Slavenko A, Itescu Y, Ihlow F, Meiri S (2016) Home is where the shell is: predicting turtle home range sizes. J Anim Ecol 85:106-114 
Stokes KL, Broderick AC, Canbolat AF, Candan O, Fuller WJ, Glen F, Levy Y, Rees AF, Rilov G, Snape RT, Stott I, Tchernov D, Godley BJ (2015) Migratory corridors and foraging hotspots: critical habitats identified for Mediterranean green turtles. Divers Distrib 21:665-674

Swimmer Y, Arauz R, McCracken M, McNaughton L, Ballestero J, Musyl M, Bigelow K, Brill R (2006) Diving behavior and delayed mortality of olive ridley sea turtles Lepidochelys olivacea after their release from longline fishing gear. Mar Ecol Prog Ser 323:253-261

Swimmer Y, McNaughton L, Foley D, Moxey L, Nielsen A (2009) Movements of olive ridley sea turtles Lepidochelys olivacea and associated oceanographic features as determined by improved light-based geolocation. Endanger Species Res 10:245254

The State of the World's Sea Turtles (2016)

Whiting S, Long J, Coyne M (2007) Migration routes and foraging behaviour of olive ridley turtles Lepidochelys olivacea in northern Australia. Endanger Species Res 3:1-9

Witt MJ, Broderick AC, Coyne MS, Formia A, Ngouessono S, Parnell RJ, Sounguet G-P, Godley BJ (2008) Satellite tracking highlights difficulties in the design of effective protected areas for Critically Endangered leatherback turtles Dermochelys coriacea during the inter-nesting period. Oryx 42:296-300

Worton BJ (1989) Kernel Methods for Estimating the Utilization Distribution in HomeRange Studies. Ecology 70:164-168 